\title{
Correction to: Group invariance of integrable Pfaffian systems
}

\section{A. Kumpera ${ }^{1}$}

Published online: 13 June 2019

(c) Fondazione Annali di Matematica Pura ed Applicata and Springer-Verlag GmbH Germany, part of Springer Nature 2019

\section{Correction to: Annali di Matematica Pura ed Applicata (1923) https://doi.org/10.1007/s10231-019-00838-9}

The article Group invariance of integrable Pfaffian systems, written by A. Kumpera, was originally published electronically on the publisher's internet portal (currently SpringerLink) on 28 March 2019 with open access. With the author(s)' decision to step back from Open Choice, the copyright of the article changed on June 2019 to (C) Fondazione Annali di Matematica Pura ed Applicata and Springer-Verlag GmbH Germany, part of Springer Nature 2019, and the article is forthwith distributed under the terms of copyright.

The original article has been corrected.

Publisher's Note Springer Nature remains neutral with regard to jurisdictional claims in published maps and institutional affiliations.

The original article can be found online at https://doi.org/10.1007/s10231-019-00838-9.

$凶$ A. Kumpera

antoniokumpera@hotmail.com

1 Universidade Estadual de Campinas (State University of Campinas), Campinas, SP, Brazil 